\title{
"Her" Marriage after the Revolutions
}

\author{
W. Bradford Wilcox ${ }^{1}$ and Steven L. Nock ${ }^{2}$
}

Recent social changes have made husbands' emotional investments and wives' perceptions of equity in the division of housework crucial for women's marital happiness. But wives are also happiest in their marriages when they share a strong normative commitment to lifelong marriage with their husbands and when their husbands take the lead in breadwinning. Thus our research suggests that elements of the new and the old promote marital happiness among contemporary wives.

KEY WORDS: marriage; wives; gender; feminism; commitment; emotion; breadwinning.

The character, quality, and stability of marriage in the United States have been transformed by two revolutionary and related trends since the mid-twentieth century. Each is the cause and consequence of demographic, technological, economic, and ideational forces. The gender revolution - involving dramatic increases in women's labor force participation and popular support for gender egalitarianism-has resulted in marriages where wives typically work, husbands do markedly more housework and childcare than they did 50 years ago, and most spouses expect that they will share, at least to some degree, the domestic, emotional, and market work associated with maintaining a family (Bianchi et al., 2006; Casper and Bianchi, 2002). The family revolution - marked by the rise of expressive individualism and a concomitant decline in the scope and normative power of the institution of marriage - has resulted in marriages that, on the one hand, focus more and more on the emotional dimensions of married life and, on the other hand, do not enjoy the stability and normative

\footnotetext{
${ }^{1}$ Department of Sociology, University of Virginia, PO Box 400766, Charlottesville, Virginia 22904-4766; e-mail: wbwilcox@virginia.edu.

${ }^{2}$ Sociology Department, University of Virginia, 543 Cabell Hall, PO Box 400766, Charlottesville, Virginia 22904; e-mail: nock@virginia.edu.
} 
commitment to lifelong marriage that earlier marriages did (Bumpass, 1990; Cherlin, 2004).

In the wake of these revolutionary and ongoing changes, we sought in a recent article in Social Forces to consider the self-reported quality of women's marriages using data from more than 5,000 married couples in the second wave (1992-1994) of the National Survey of Families and Households (Wilcox and Nock, 2006). Three core questions animated our research: (1) How important is men's emotion work (Hochschild, 1979) - their affection, empathy, and quality time devoted to the marriage - to women's marital happiness? (2) Are women in marriages organized along more egalitarian lines happier than wives in marriages organized along more gendered lines? (3) Are women in marriages organized along more institutionalized lines - that is, where both spouses subscribe to a variety of traditional marriage norms - happier than women who do not share a strong normative commitment to the institution of marriage with their husbands?

Given the increasingly expressive character of contemporary marriages, we hypothesized, and found, that the emotional investments of husbands in married life far surpass factors such as the division of market and domestic work, gender ideology, and religious attendance in predicting women's marital quality. Specifically, we found that wives were significantly happier in their marriages if they also reported that they were happy with their husbands' affection and understanding and/or if their husbands reported spending a lot of time with their wives "talking or sharing an activity." "Her" happiness in marriage, it would seem, is strongly related to "His" efforts to be emotionally engaged and available and to "Her" expectations of what he should and can do emotionally for the marriage.

To answer the second set of questions, we sought to test four theories of marital functioning to determine what other factors are associated with wives' reports of marital happiness. We evaluated a "companionate model" of marriage that suggests that egalitarian patterns of work, earning, and housework in marriages foster greater emotional intimacy and more emotion work on the part of husbands by blurring any distinctive roles of husbands and wives and eliminating patriarchal patterns of power and authority (England and Farkas, 1986). We also tested a competing "gender model" of marriage that suggests wives - even egalitarian-minded wives - will be happier in marriages organized along gender-typical ideals where husbands take the lead in breadwinning and wives take the lead in homemaking and childcare, in part because men and women have been socialized to value distinctively gendered patterns of behavior in the family (West and Zimmerman, 1987).

We evaluated another pattern that we called the "equity model." The logic here is that women's marital happiness depends to some degree on 
their sense that the division of housework is fair; a determination that is shaped not only by their husbands' contributions to housework (and other tasks including breadwinning) but also by their ideological commitment to gender equality or traditionalism (Hochschild and Machung, 1989). And we tested an "institutional model" of marriage to see if wives are happier when they share a strong commitment to the norm of lifelong marriage with their husbands. Such wives have been argued to construct a "family myth" (Hochschild and Machung, 1989) that they are happy with their marriage regardless of their husband's behavior. Other work suggests that husbands who are committed to marriage are also more likely to invest emotionally and practically in their marriages, to be sexually faithful, and to engender a sense of trust and security in their wives (Wilcox, 2004; Wilcox and Nock, 2006).

So what did we find? We found no evidence for the companionate model, no indicator of egalitarianism, from ideology to the division of housework to women's labor force participation, was linked to wives' marital happiness. On the other hand, we found significant support for the gender model of marriage: more traditional-minded women, women who did not work outside the home, and women whose husbands earned more than two-thirds of the family's income all reported that they were happier in their marriages. Interestingly, ancillary analyses indicate that the gender model even applied to women who held more egalitarian gender attitudes, that is, women who registered gender attitudes above the median in our scale of gender attitudes (which tapped views on sharing housework, working mothers, and a traditional division of labor).

Our results also indicate that a sense of equity is important for marital happiness among women. Women who judged the division of housework fair in their marriages were much more likely to report that they were happy in their marriages. Finally, we found that women who shared a strong normative commitment to marriage with their husbands were more likely to be happy in their marriages, compared with women who did not.

How do we account for our findings? When it comes to the gender model, our findings indicate that more traditional-minded women are more likely to view their husbands' domestic and emotion work through rose-colored lenses and that they are more likely to share a strong normative commitment to marriage with their husbands. We think stay-at-home wives are happier in part because they are "doing gender" in a stereotypical way (West and Zimmerman, 1987). More importantly, ancillary analyses also indicate that the stay-at-home wife finding is strongest for wives with children at home suggesting that spouses with children at home may find it easier to focus on their marriages when the wife is not juggling married life, childrearing, and work all at the same time. Note, for 
instance, that recent research finds that stay-at-home married mothers spend more time with their husbands than do working married mothers (Bianchi et al., 2006). Finally, we think wives whose husbands earn the larger share of income are happier for three reasons: first, their husband is successfully fulfilling a gendered providership role; second, these women are less likely to view the typical husband's relatively smaller contribution to housework as unfair; and, third, their husband's success as a breadwinner may give them choices to stay at home, hold an interesting but not particularly renumerative job, or pursue a personal hobby.

With regard to the equity model, our study indicates that women's perceptions of equity - but not an equal division of domestic or market work - are important predictors of marital happiness for wives. Note, of course, that only about one-third of the wives in our study report that the division of housework is unfair, even though most wives take the lead in housework. We suspect that husbands' domestic, emotional, and market contributions to the family all figure in women's perceptions of equity, and that women can and often do view unequal contributions to housework as "fair" when husbands are, say, taking the lead in breadwinning. Note here that studies indicate that husbands and wives now devote, on average, about the same total hours of domestic and market work to their families, even though wives devote more of this time to domestic work, and husbands devote more of this time to market work (Bianchi et al., 2006). We also think that women who hold more traditional gender views are less likely to attach a great deal of importance to an egalitarian division of housework (Demaris and Longmore, 1996). Finally, in our study, we find that wives who report that the division of housework is "unfair" are less likely to have husbands who spend quality time with them and are also less likely to be happy with their husbands' affection and understanding; we suspect that such wives may enter into conflict with their husbands and that their husbands may retaliate by cutting back on their emotional engagement.

The institutional model of marriage is also supported by our study. Wives who share a strong commitment to the norm of lifelong marriage with their husband - e.g., who both believe that even unhappily married couples should stay together for the sake of their children-are more likely to have a happy marriage than couples who do not share this commitment to marriage. Shared commitment seems to generate a sense of trust, emotional security, and a willingness to sacrifice for one's spouse on the part of couples all of which lead to happier marriages for women (Amato and Rogers, 1999). This shared commitment also provides women with a long-term view of their marriage that may help them negotiate the inevitable difficulties that confront any marriage (Nock, 2000). Finally, married women who are strongly committed to the norm of lifelong mar- 
riage are probably more likely to construct a "family myth" that they are happy in their marriages to legitimate their investment in the marriage, above and beyond their husbands' practical, emotional, and financial contributions to the marriage (Hochschild and Machung, 1989).

The men and women swept along by the prodigious changes we call the gender and family revolutions took different paths in how they arranged their marriages. The "models" we tested summarize those divergent arrangements. We do not yet know how or why one arrangement rather than another emerges. Nor do we know how one changes into another. The practical press of paying bills, dealing with ex-spouses, balancing complex lives, and reconciling hopes and realities all play a role, to be sure. But regardless of the dynamics involved, our work suggests that wives typically find some arrangements superior to others.

Taken together, our results suggest that women are happier in marriages that combine elements of the new - an emotionally engaged husband, as well as a husband who does his fair share - and elements of the old - a husband who takes the lead in breadwinning, a wife who stays at home, and a shared commitment to the norm of lifelong marriage. Obviously, our findings in support of the institutional and gender models are controversial. Is it possible that we are wrong?

Yes, and in three ways. First, because our data are more than a decade old, it is possible that contemporary marriages have changed in ways that make egalitarian or low-commitment marriages happier for women. Second, because our data are cross-sectional, it may well be that marital unhappiness on the part of women leads them to focus on work or reduce their commitment to the norm of lifelong marriage, rather than vice versa (e.g., Rogers and DeBoer, 2001). Third, it may be that some unmeasured exogenous factor or factors - say, a happy disposition or supportive extended kin accounts for some of our findings. For instance, the link between normative commitment to marriage and women's marital happiness may jointly result from such factors. So, future research will have to examine these possibilities.

Future research should also focus on wives' decisions to "opt out" or "opt into" the workforce and how these decisions are related to increases or decreases in marital quality, particularly with an eye to the ways in which husbands' domestic, emotional, and earnings contributions or a shared commitment to the norm of lifelong marriage modify the effect of wives' entries into or exits from the labor force. It may be, for instance, that husbands and wives are better able to weather any challenges associated with nontraditional gender arrangements if they share a strong commitment to the institution of marriage (Brines and Joyner, 1999). Future research should also seek to determine if women are willing to put up with a measure of marital unhappiness or stress - associated, for instance, with 
juggling motherhood, work, and married life - if they are able to pursue other goals - e.g., financing their children's education, professional accomplishment, etc.

Despite the limitations of our research and the need for future work to confirm our theoretical claims, we do think our research - and the larger body of research on marriage - allows us to size up the impact of the family and gender revolutions on "her" marriage. Our research, along with the research of other family scholars (Amato and Rogers, 1999; Amato et al., 2003; Glenn, 1991), strongly suggests that the constellation of social forces that produced the family revolution undercut not only the stability but also the quality of contemporary marriages. Declines in popular support for an ethic of lifelong marriage over the last half-century seem to have made contemporary couples less willing to sacrifice for one another, to invest in their marriages, and to take the long view when they confront the inevitable challenges of married life. Our study suggests that the quality of married life for wives declined in recent years in part because Americans became less committed to a marital ethic of "till death do them part." In other words, average married women have probably not been uniformly well served by the family revolution that swept this country from the 1960s to the present (Cherlin, 2004).

The impact of the gender revolution on "her" marriage seems more ambiguous. On the one hand, the gender revolution - and feminism in particular - has clearly encouraged men to be more emotionally and practically engaged in the life of their marriages (McQuillan and Marx Ferree, 1998). So the comparatively high level of practical and emotional engagement that many wives now enjoy would seem to be indebted to the influence of the gender revolution. On the other hand, insofar as the gender revolution undercut opportunities for men to make a unique contribution to their marriages and families as breadwinners, our study suggests that it may have caused trouble for marriages (see also Nock, 2001). The gender revolution has also raised expectations of equality among some married women, expectations that are often dashed by husbands who are unwilling or unable to meet those expectations (Chafetz, 1995). In these ways, the gender revolution has, in all likelihood, contributed to both increases and declines in women's perceptions of marital quality over the last half-century.

Where does all this leave married women at the beginning of the twenty-first century? We are surprisingly hopeful about the future of marriage for women who are fortunate enough to enter into it. The increasing popularity of "choice feminism"- the idea that all women's work-family choices are equally legitimate (Hirshman, 2005) - suggests that married women, even feminist-minded women, will feel free to "opt out" of the labor force or let their husbands take the lead in breadwinning if either of 
these options look best for them and their families and, indeed, the employment rate of married mothers stopped increasing around 1990 and has remained relatively stable through 2004 (U.S. Bureau of the Census, 2006). Furthermore, recent efforts on the part of corporations to promote flextime, telecommuting, and part-time work for their employees should enable both married men and women to combine marriage, parenthood, and work in ways that do not harm their marriages. Indeed, some research suggests that such arrangements are associated with greater happiness among married mothers (Jackson and Scharman, 2002). If these cultural and policy developments allow women to better match their preferred work-family strategies with their actual strategies, women will probably enjoy more happiness in their marriages and, more generally, in their lives (Hakim, 2001).

Finally, we also think that recent increases in pro-marriage attitudes and declines in the divorce rate augur well for married women (Whitehead and Popenoe, 2004). In recent years, data from "Monitoring the Future" indicates that teenagers are more likely to say that having a good marriage and family life is "extremely important" to them. Divorce rates have fallen modestly but consistently since the early 1980s. A continuing uptick in the practice and norm of lifelong marriage would be valuable to all married women, insofar as it fosters trust, mutual sacrifice, and a longterm view. Interestingly, such a surge in support for the institution of marriage might be particularly valuable to feminist-minded wives and to working wives. Previous research (Brines and Joyner, 1999) and our own ancillary analyses suggest that women and men can better pursue nontraditional work-family strategies if they enjoy and are committed to the norms of loyalty and fidelity associated with the institution of marriage. In other words, even for dedicated pioneers in the gender revolution, the route to marital happiness may lie through old-fashioned commitment.

\section{ACKNOWLEDGMENT}

We thank Mary Caler for her research assistance.

\section{REFERENCES}

Amato, Paul R., and Stacy J. Rogers

1999 "Do Attitudes toward Divorce Affect Marital Quality?" Journal of Family Issues 20: 69-86.

Amato, Paul R., David R. Johnson, Alan Booth, and Stacy J. Rogers

2003 "Continuity and Change in Marital Quality between 1980 and 2000,'
Journal of Marriage and Family 64: $1-22$.

Bianchi, Suzanne M., John P. Robinson, and Melissa A. Milkie

2006 Changing Rhythms of American Family Life. New York: Russell Sage. 
Brines, Julie, and Kara Joyner

1999 "The Ties that Bind: Principles of Cohesion in Cohabitation and Marriage," American Sociology Review 64: 333-355.

Bumpass, Larry L.

1990 "What's Happening to the Family? Interactions between Demographic and Institutional Change," Demography 27: 483-498.

Casper, Lynn M., and Suzanne M. Bianchi

2002 Continuity and Change in the American Family. Thousand Oaks, CA: Sage.

Chafetz, Janet Saltzman

1995 "Chicken or Egg? A Theory of the Relationship between Feminist Movements and Family Change," In K.O. Mason and A. Jensen (eds.), Gender and Family Change in Industrialized Countries: pp. 63-81. Oxford: Clarendon Press.

Cherlin, Andrew J.

2004 "The Deinstitutionalization of American Marriage," Journal of Marriage and Family 66: 848-861.

Demaris, Alfred, and Monica Longmore

1996 "Ideology, Power, and Equity: Testing Competing Expectations for the Perception of Fairness in Household Labor," Social Forces 74: 1043-1071.

England, Paula, and George Farkas

1986 Households, Employment, and Gender. New York: Aldine de Gruyter.

Glenn, Norval D.

1991 "The Recent Trend in Marital Success in the United States," Journal of Marriage and the Family 60: 261-270.

Hakim, Catherine

2001 Work-Lifestyle Choices in the 21st Century: Preference Theory. New York: Oxford University Press.

Hirshman, Linda

2005 "Homeward Bound," The American Prospect Online Edition. (http://www. prospect.org/web/page.ww?section= root\&name $=$ viewPrint\&articleId $=$ 10646)

Hochschild, Arlie

1979 "Emotion Work, Feeling Rules, and Social Structure," American Journal of Sociology 85: 551-575.
Hochschild, Arlie, and Ann Machung

1989 The Second Shift: Working Parents and the Revolution at Home. New York: Viking.

Jackson, Aaron P., and Janet S. Scharman

2002 "Constructing Family-Friendly Careers: Mother's Experiences," Journal of Counseling and Development 80: 180-187.

McQuillan, Julia, and Myra Marx Ferree

1998 "The Importance of Variation among Men and the Benefits of Feminism for Families," In A. Booth and A. Crouter (eds.), Men in Families: When Do They Get Involved?: pp. 213-225. Mahwah, NJ: Lawrence Erlbaum.

Nock, Steven L.

2000 "Time and Gender in Marriage," Virginia Law Review 86: 1971-1987.

Nock, Steven L.

2001 "The Marriages of Equally Dependent Spouses," Journal of Family Issues 22: 755-775.

Rogers, Stacy J., and Danielle D. DeBoer

2001 'Changes in Wives' Income: Effects on Marital Happiness, Psychological Well-being, and the Risk of Divorce," Journal of Marriage and Family 63: 458-472.

U.S. Bureau of the Census

2006 Statistical Abstract of the US, Table 586. Washington, DC.

West, Candace, and Don H. Zimmerman

1987 "Doing Gender," Gender and Society 1: $125-151$.

Whitehead, Barbara Dafoe, and David Popenoe

2004 The State of Our Unions: 2004. New Brunswick, NJ: National Marriage Project.

Wilcox, W. Bradford

2004 Soft Patriarchs, New Men: How Christianity Shapes Fathers and Husbands. Chicago: University Chicago Press.

Wilcox, W. Bradford, and Steven L. Nock 2006 "What's Love Got to Do with It? Equality, Equity, Commitment and Women's Marital Quality," Social Forces 84: 1321-1345. 